https://www.scopus.com/results/authorNamesList.uri?sort=count-f\&src=al\&sid=bc9f82417433b8affca9a7fa80f3e679\&sot=al\&sdt= al\&sl=43\&s=AUTHLASTNAME\%28klishch\%29+AND+AUTHFIRST\%28Halyna\%29\&st1=klishch\&st2=Halyna\&orcidId=\&selec tionPageSearch=anl\&reselectAuthor=false\&activeFlag=true\&showDocument=false\&resultsPerPage=20\&offset=1\&jtp=false \&curre ntPage=1\&previousSelectionCount $=0$ \& tooManySelections $=$ false\&previousResultCount $=0$ \&authSubject $=$ LFSC\&authSubject $=$ HLSC \&authSubject=PHSC\&authSubject=SOSC\&exactAuthorSearch=false\&showFullList=false\&authorPreferredName=\&origin=searcha uthorfreelookup\&affiliationId=\&txGid=2c497899ab5d6e4078f583af97c0d1a5

www.Scopus.com/results/authorNamesList uri?sort=count-f\&src=al\&sid=374dae6cdf5bf4c73249b641901be32 =46\&s=AUTHLASTNAME\%28Yelahina\%29+AND+AUTHFIRST\%28Nataliia\%29\&st1=Yelahina\&st2=Nataliia\&orcidId=\&selecti onPageSearch=anl\&reselectAuthor=false\&activeFlag=true\&showDocument=false\&resultsPerPage=20\&offset=1\&jtp=false\&current Page=1\&previousSelectionCount $=0$ \& tooManySelections $=$ false\&previousResultCount $=0$ \&authSubject $=$ LFSC \&authSubject $=$ HLSC $\&$ authSubject=PHSC\&authSubject=SOSC\&exactAuthorSearch=false\&showFullList=false\&authorPreferredName=\&origin=searchaut horfreelookup\&affiliationId=\&txGid=ede5903a78f2661393eb170f025fa14c

T. I. Горпініч

ORCID 0000-0003-2160-4535

ResearcherID B-2428-2016

Scopus Author ID 57202830426

ДВНЗ «Тернопільський державний медичний університет

імені І. Я. Горбачевського МОЗ Украӥни»

\title{
ІНШОМОВНА ГРАМАТИЧНА КОМПЕТЕНТНІСТЬ ЯК СКЛАДОВА ЗАГАЛЬНОЇ ПІДГОТОВКИ МАЙБУТНЬОГО ЛІКАРЯ У КОНТЕКСТІ ВІРТУАЛЬНО-НАВЧАЛЬНОГО СЕРЕДОВИЩА
}

\author{
N. O. Fedchyshyn, H. I. Klishch, N. I. Yelahina, T. I. Horpinich \\ I. Horbachevsky Ternopil State Medical University \\ FOREIGN LANGUAGE GRAMMATICAL COMPETENCE AS A \\ COMPONENT OF THE GENERAL TRAINING OF FUTURE DOCTORS IN \\ THE VIRTUAL LEARNING ENVIRONMENT
}

\begin{abstract}
Анотація. У статті узагальнено досвід використання віртуальної навчальної програми на заняттях з іноземної мови за професійним спрямуванням у студентів-медиків. Розкрито практичний аспект формування граматичних навичок та вмінь (граматичної компетентності, повторення вивченого матеріалу) шляхом використання на заняттях з іноземної мови віртуальних програм. Розглянуто загальні науково-методичні підходи до використання віртуальних веб-орієнтованих освітніх середовищ для вивчення іноземної мови професійного спрямування студентами-медиками у вищих медичних навчальних закладах. Представлено віртуальну інформаційну модель з німецької мови за професійним спрямуванням «Augenerkrankungen» та доведено ефективність використання віртуальних навчальних програм загалом.
\end{abstract}


Розвиток граматичної компетентності студентів-медиків шляхом використання віртуальної програми сприяє не лише якісному урізноманітненню та інтенсифікації освітнього процесу, але й значному підвищенню рівня знань та іншомовно-комунікативної компетентності студентів. Тому впровадження ІТ-технологій у навчальний процес вимагає розробки відповідної науковометодичної бази, інструментальних засобів і систем комп’ютерного навчання та контролю знань, системної та раціональної інтеграції цих технологій в існуючі навчальні програми.

Ключові слова: віртуальна навчальна програма; формування граматичних навичок; вивчення німецької мови професійного спрямування; IКТ-технології; сценарій віртуальної програми; студент-медик.

Abstract. The article summarizes the experience of using the virtual training program at the lessons of foreign language for specific purposes for medical students. Practical aspect of formation of grammatical skills and abilities (grammatical competence, repetition of the acquired material) through the use of virtual programs at foreign language classes is revealed. General scientific and methodical approaches to the use of virtual web-oriented learning environment in studying foreign language for specific purposes by medical students in higher educational institutions are considered. The virtual information model “Augenerkrankungen” in the German language for specific purposes is presented. The efficiency of the use of virtual training programs in general is proved.

Development of medical students' grammatical competence through the use of a virtual program contributes not only to the qualitative diversification and intensification of the educational process, but also to a significant increase of knowledge and students' foreign language communicative competence. Therefore, implementation of the information and communication technologies (ICT) in the educational process requires the development of an appropriate scientific and methodological base, tools and systems for computer training and knowledge control, systematic and rational integration of these technologies into existing curricula.

Key words: virtual training program; formation of grammatical skills; the German language for specific purposes learning; ICT; virtual program scenario; medical student.

Вступ. Сучасна модернізація усіх сфер суспільних відносин, перетворення, що відбуваються в нашій країні, приводять до корінних змін в освіті, з'являються нові, вищі вимоги до навчання, виховання і розвитку молоді. В умовах сучасних суспільно-економічних відносин, росту і розвитку міжнародних контактів, необхідно досягти такого рівня підготовки в загальноосвітніх навчальних закладах, при якому спеціалісти будуть спроможні брати участь у міжкультурній комунікації іноземною мовою і самостійно вдосконалюватися. Тому пошуки шляхів підвищення ефективності навчання набувають зараз все більшої актуальності.

Фахівці XXI ст. значно відрізняються від попередніх поколінь, саме тому ми повинні шукати нові методи та підходи, які зможуть не лише зацікавити, але й працювати наполегливо задля досягнення результату. Доповнення існуючих підручників новим, живим, цікавим матеріалом сприятиме і формуванню іншомовної лексичної компетентності при використанні у навчальному середовищі IKTтехнологій, зокрема віртуальних програм.

Дослідженню даного питання присвячено праці науковців В. Бикова, В. Вембер, М. Жалдака, Н. Морзе, С. Литвинової та ін. Незважаючи на плідність запропонованих у їх наукових працях ідей та технологій, спеціальних досліджень щодо практичного аспекту використання у навчальному середовищі вищої школи вченими і практиками розкрито недостатньо. Результати аналізу досліджень свідчать, що у вітчизняних працях основні зусилля зосереджено на висвітленні теоретико-методологічних аспектів проблеми, тоді як практич- ний аспект даного питання потребує більш ширшого розкриття. Поняття віртуальної реальності $\epsilon$ чи не найбільш згадуваним в IT-новинах. Все частіше за допомогою різноманітного обладнання і технологій, а головне - нових ідей, IT-технології активно реалізуються у навчальному середовищі.

Мета дослідження - розкрити практичний аспект формування граматичних навичок та вмінь у студентів-медиків шляхом використання на заняттях з іноземної мови віртуальних програм.

Методи дослідження. Новітні тенденції використання інформаційно-комунікаційних технологій при викладанні іноземних мов вимагають від викладача нових рішень щодо проведення навчальної роботи зі студентами. Такі можливості сприяють не лише якісному урізноманітненню та інтенсифікації освітнього процесу, але й значному підвищенню рівня знань та іншомовно-комунікативної компетентності студентів. Впровадження IT-технологій у навчальний процес вимагає розробки відповідної науково-методичної бази, інструментальних засобів і систем комп'ютерного навчання та контролю знань, системної і раціональної інтеграції цих технологій в існуючі навчальні програми та організаційні структури. Класичні методи вивчення іноземних мов часто є нецікавими, можуть давати повільніший результат [1]. Тому поруч із традиційними формами роботи варто урізноманітнити навчальний процес за допомогою сучасних технічних засобів, які спрямовані на самопідготовку, коли викладач виступає лише координатором дій.

Мультимедійні засоби дозволяють задіяти майже всі органи чуття студентів, поєднуючи друкований 
текст, графічне зображення, рухоме відео, статичні фотографії, створюючи «віртуальну реальність» справжнього спілкування. Науковцями доведено, що застосування мультимедійних матеріалів та комп’ютерних мереж скорочує час навчання майже втричі, а рівень запам'ятовування через одночасне використання зображень, звуку, тексту зростає на 30-40\% [2].

Перевагою таких форм і методів є встановлення студентом свого власного ритму навчання, який досягається особистісно-зорієнтованим підходом до навчання. Саме тому використання інформаційно-комунікативних технологій, зокрема віртуальних програм, у процесі викладання іноземних мов значно розширить та урізноманітнить мотивацію студентів-медиків до навчання, надаючи їм можливість працювати над іноземною мовою у зручному для них темпі та сприяти, таким чином, індивідуалізації навчання й ефективному вдосконаленню комунікативних навичок з іноземної мови у ВНЗ.

Оскільки впровадження таких технологій в освітній процес є обов’язковим і відбувається на досить інтенсивному рівні, потрібно чітко виокремити психолого-педагогічні та дидактичні принципи створення і використання нових педагогічних технологій. Це стосується, насамперед, ролі викладача, якому потрібно не тільки ефективно і раціонально поєднувати традиційні та новітні технології навчання, правильно використовувати сучасні технології, удосконалювати й постійно розширювати свої знання та навички, а й мотивувати студентів до творчого пошуку і пізнавальної діяльності, забезпечити доступ до різноманітних автентичних матеріалів (мовний матеріал, доступ до інтегрованих баз даних, довідників, інтерактивний режим доступу до навчального матеріалу, матеріали інформаційних сайтів тощо).

Поєднання засобів IKT разом із традиційними засобами навчання (підручники, посібники тощо) безумовно додатково забезпечують практичну спрямованість навчального процесу та допомагають створити реальні можливості застосування студентами набутих компетенцій. За рахунок інтенсифікації сприйняття студентами навчального матеріалу стає можливим залучити їх до процесу пізнання як суб’єктів навчальної діяльності. Важливою властивістю таких засобів також є інтерактивність, яка сприяє забезпеченню зворотного зв’язку. Використання комп'ютерних технологій у викладанні іноземної мови дозволяє підвищити індивідуалізацію навчальної діяльності студентів, оптимізувати засвоєння мовних структур та гра- матичних правил, а також подолати монотонність заняття при формуванні мовленнєвої та комунікативної компетенції студентів-медиків.

На практичних заняттях із використанням комп’ютера значно зростає мотивація студента до навчання, адже саме завдяки такій роботі студент може позбутися однієї з головних причин негативного ставлення до навчання - відсутності успіху. Використання комп'ютерної техніки робить заняття привабливим та сучасним.

Одержавши навчальні матеріали в електронному i/чи друкованому вигляді з використанням телекомунікаційних мереж, студент може опановувати іноземну мову вдома, на робочому місці чи будьде. Комп’ютерні системи можуть проекзаменувати, виявити помилки, дати необхідні рекомендації, здійснити практичне тренування, відкрити доступ до електронних бібліотек, за лічені секунди знайти потрібну цитату, абзац чи параграф. Навчальні курси супроводжуються ігровими ситуаціями, оснащені термінологічним словником і відкривають доступ до основних вітчизняних та міжнародних баз даних і знань на будь-якій відстані й у будь-який час. У віртуальній формі навчання стає багатокомпонентною інтелектуальною працею, оскільки забезпечує інтерактивну взаємодію студентів із сукупним (викладачі плюс інші студенти) суб’єктом інформаційного середовища. Середовище стає одночасно предметом інтелектуальної діяльності і її (середовище плюс студент) суб’єктом. Середовище виступає як засіб розширення свідомості та пам’ яті людини і стає формою буття індивідуальної свідомості та пам’яті.

Результати дослідження. У Тернопільському державному медичному університеті імені I. Я. Горбачевського створено відділ віртуальних навчальних програм. Завдання цього відділу - створення та впровадження навчального програмного забезпечення на кафедрах університету і подальше використання студентами у навчально-практичній роботі, створення бази віртуальних навчальних програм й апробація та вдосконалення уже розроблених програм. Основні функції відділу: 1) технічна підготовка навчального віртуального забезпечення; 2) моніторинг створених віртуальних навчальних програм, якими користуються студенти, та розроблених іншими ВНЗ; 3) вдосконалення створеного віртуального навчального забезпечення; 4) розробка віртуальної бази матеріалів для створення навчального матеріального забезпечення; 5) впровадження віртуальних навчальних програм 
у навчальний процес університету; 6) подання заяв на реєстрацію авторських прав на створені віртуальні навчальні матеріали. На даний час студенти користуються віртуальними навчальними програмами для вивчення німецької мови професійного спрямування.

Створення навчальної системи з використанням інструментальних програм звичайно проходить певні стадії: 1. Розробка сценарію навчальної про- грами: на цій стадії розробник повинен ухвалити рішення щодо того, який розділ якого навчального курсу він буде переводити в навчальну програму, продумати матеріал інформаційних кадрів, такі питання й варіанти відповідей до них, щоб вони діагностували труднощі, з якими будуть зустрічатися студенти при освоєнні матеріалу, розробити схему проходження програми, систему взаємозв’язків між її окремими кадрами й фрагментами (рис. 1).

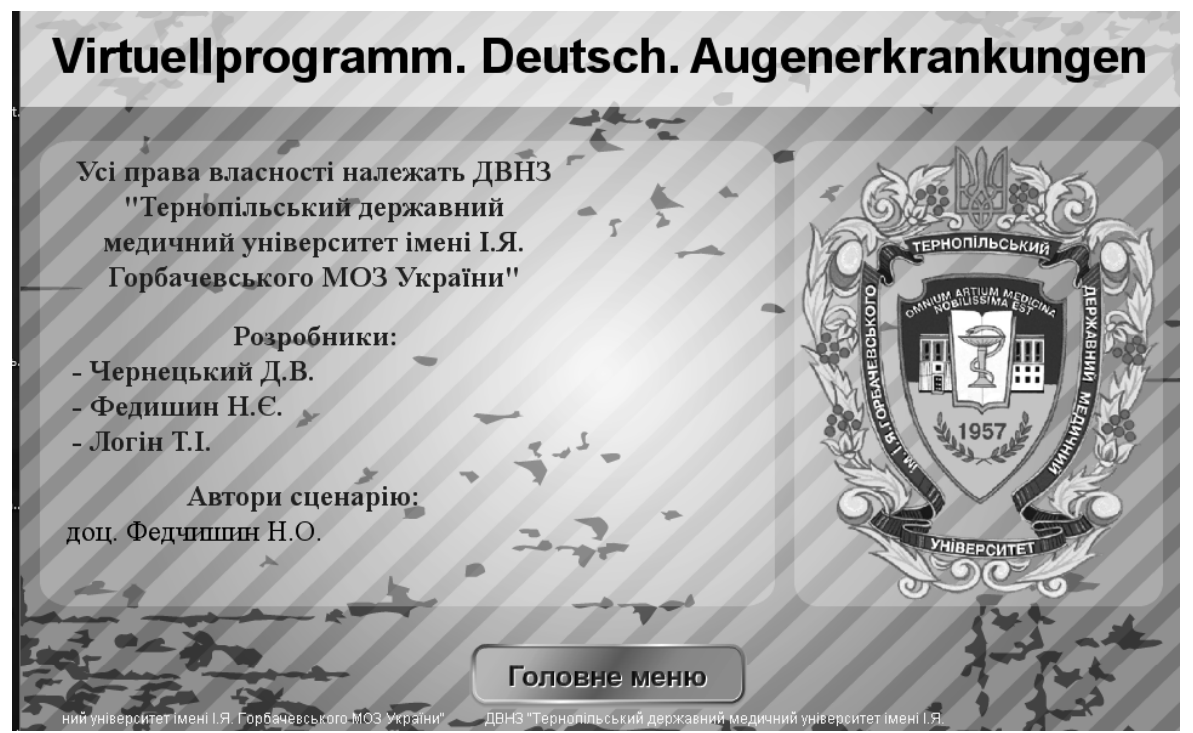

Рис. 1. Віртуальна програма з німецької мови за професійним спрямуванням «Захворювання ока».

2. Уведення текстів окремих кадрів майбутньої програми, малювання картинок, формування контролюючих фрагментів: питань, варіантів відповідей до них і способів аналізу правильності відповідей. На цій стадії розробникові буде потрібне володіння функціями комп’ютера й можливостями введення й редагування, вбудованими в інструментальну програму. Так, для майбутніх лікарів за навчальним планом з німецької мови за професійним спрямуванням передбачено вивчення систем людини. Цілком логічно тематика віртуальних програм пропонує такі теми, як «Augenerkrankungen», «Ohrerkrankungen», «Atmungssystem» тощо.

Відтак для аналізу ми виокремили віртуальну програму «Augenerkrankungen». Відповідно, всі наявні програми пропонують насамперед завдання на аудіювання, адже аудіювання або прослуховування визначається як процес розпізнання і розуміння мови носія (рис. 2). Воно включає в себе розуміння акценту мовця або вимови, граматику, словниковий запас та розуміння тексту. Слухач має бути здатним виконувати всі ці завдання одночасно, оскільки прослуховування $є$ важливим у процесі вивчення німецької мови за професійним спрямуванням.
Німецькомовні вчені К. Аркоссі (K. Arkossy), Й. Фрітцше (J. Fritzsche), К. Чекан (K. Tschekan) розглядають аудіювання як основне мовне вміння $[4,5]$, адже слухач у такому разі може більш детально сприймати інформацію, різноманітні ідеї та їх розуміння [3]. Для поліпшення здатності прослуховування інформації студентами-медиками на заняттях з іноземних мов можна використовувати як аудіозаписи, програмні сервіси, так і послуговуватися тематичним відеороликом.

Так, для вивчення й закріплення граматичного матеріалу з теми «Augenerkrankungen» слід виконати ряд завдань: по-перше, за темою заняття студентам запропоновано перегляд відеофільму, що стосується теми, та дати відповіді на запитання для перевірки в студента розуміння почутого й побаченого (рис. 3). Таким чином, це надає змогу рухатися поступово від простого до більш складного відповідно до здібностей. Наприкінці цього виду роботи студент має змогу побачити результат виконаної роботи. Поєднання відео, звуку, графіки, анімації сприятимуть підвищенню мотивації студентів та розвитку їх словникового запасу. 


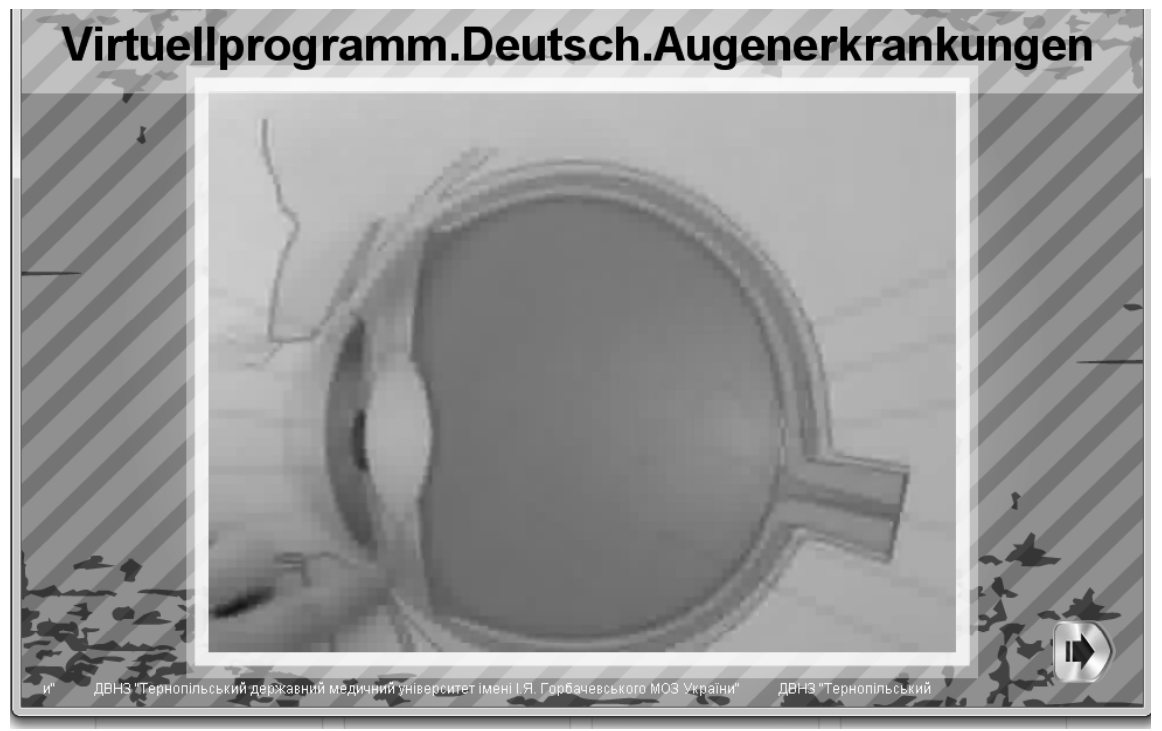

Рис. 2. Попередній перегляд відеофільму.

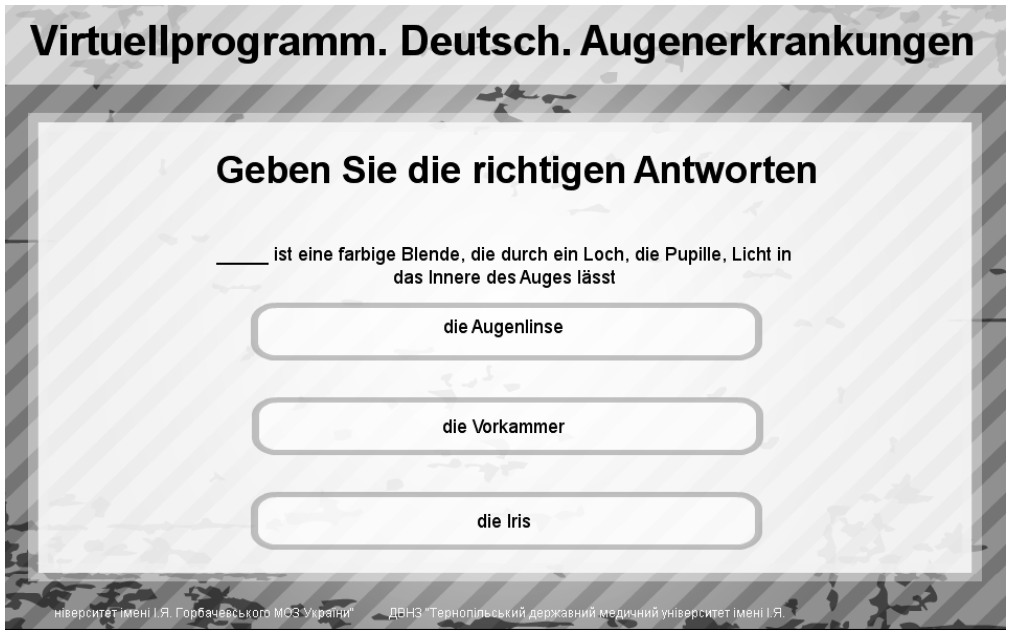

Рис. 3. Типові запитання до навчального відеофільму.

По-друге, використовуючи віртуальну програму для вдосконалення навичок з іноземної мови, студентам пропонуються після перегляду відеотексту комп’ютерні завдання із заданої тематики у вигляді вправ, тестів для розвитку граматичних вмінь. Таким чином, це дасть змогу студентам удосконалити та збагатити свій лексичний мінімум. Перегляд фільмів в оригіналі значно впливає на процес вивчення мови, формування комунікативних компетентностей студента (рис. 4).

По-третє, навчання за допомогою віртуальної програми сприяє формуванню у студентів-медиків рефлексії своєї діяльності, дозволяє побачити результат своїх дій. Таке навчання забезпечує й всебічний (поточний, рубіжний, підсумковий) контроль навчального процесу, що є невід'ємною складовою навчання й виконує функцію зворотного зв’язку. Для вдосконалення навичок граматичного мінімуму та закріплення граматичного матеріалу до теми «Augenerkrankungen» майбутні медики мають вправлятися у виконанні вправ для формування професійної граматичної компетентності (рис. 5, 6).

Процес написання є для студента при вивченні німецької мови дещо нудним. Зважаючи на це, у віртуальній програмі запропоновано виконувати завдання, які перевіряють і граматику, і лексику, а процес виконання є набагато простішим i приємнішим. Автоматичне підкреслення помилок у тексті сприятиме, окрім граматичного, і візуальному запам'ятовуванню (рис. 7,8 ). Тому вивчення іноземної мови за допомогою віртуальної програми як додаткового виду роботи сприятиме більшому бажанню студента засвоїти пропонований матеріал.

Відтак зв’язування окремих елементів віртуальної навчальної програми в цілісну діалогову систему, установлення взаємозв’язків між кадрами, 


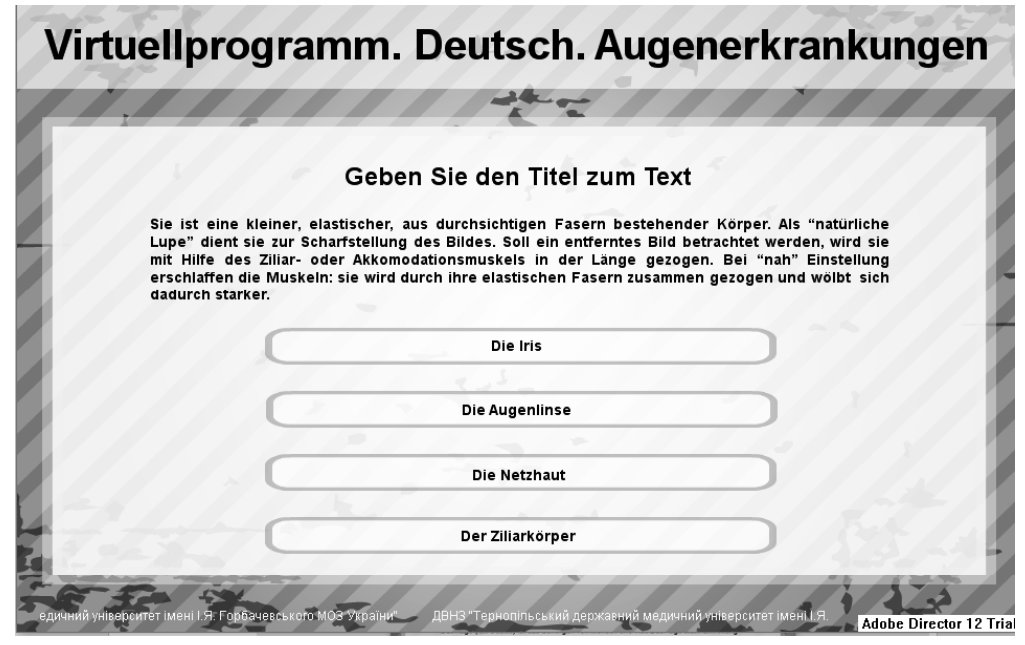

Рис. 4. Структура завдань.

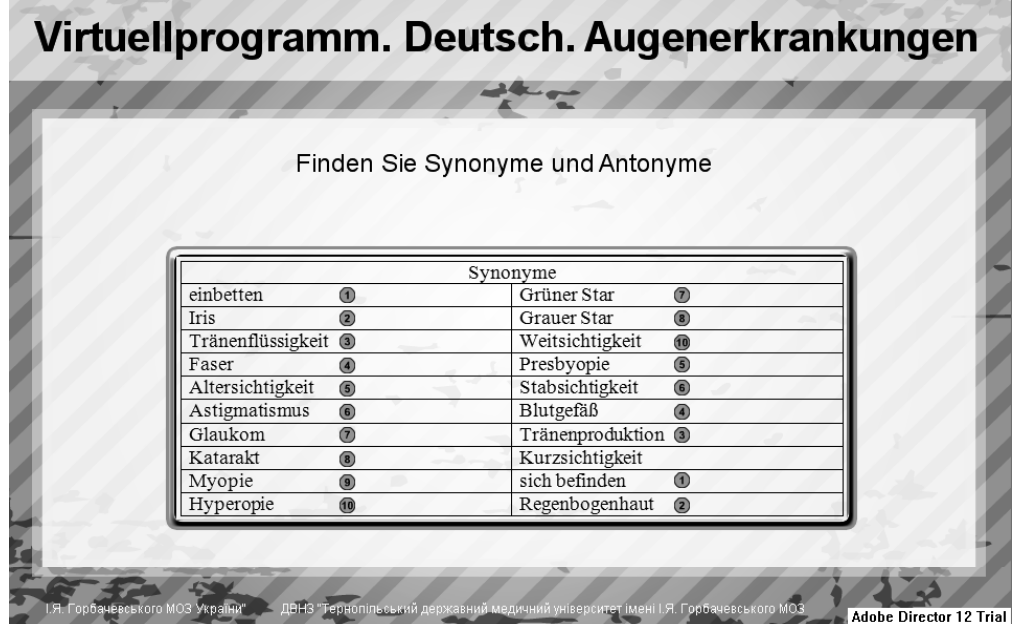

Рис. 5. Правильне визначення синонімів.

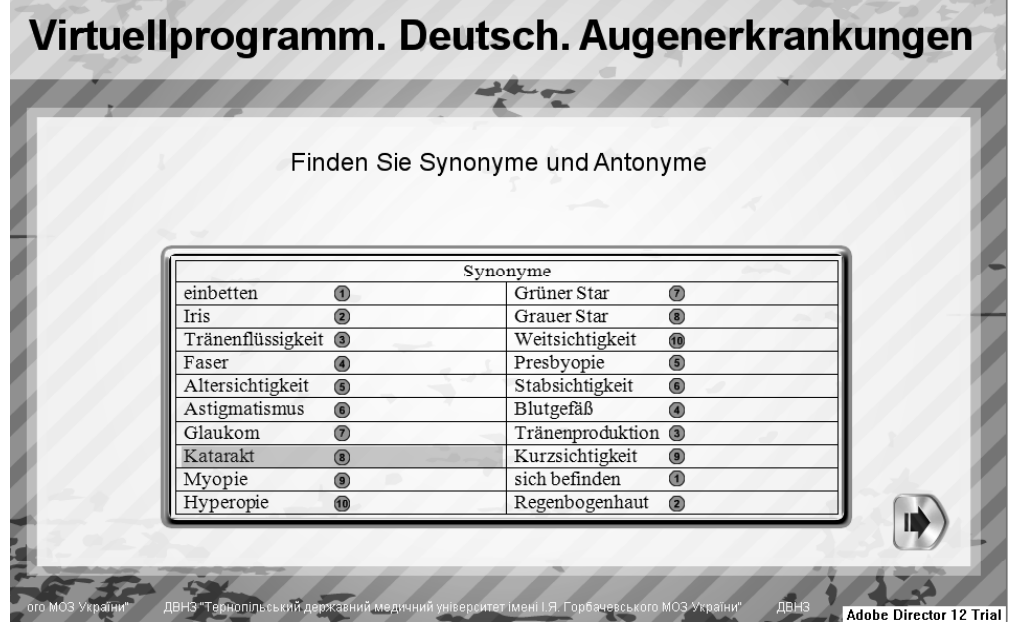

Рис. 6. Похибки при виконанні вправи.

питаннями і завданнями вибудовує цілісну систему для вдосконалення мовних навичок. Супровід програми під час її експлуатації, внесення в неї виправлень і доповнень, необхідність яких виявляється при її використанні в реальному про- цесі навчання, дозволяє дати певну оцінку її використання.

Моніторингове дослідження щодо вивчення німецької мови за професійним спрямуванням 3 використанням віртуальної навчальної програ- 


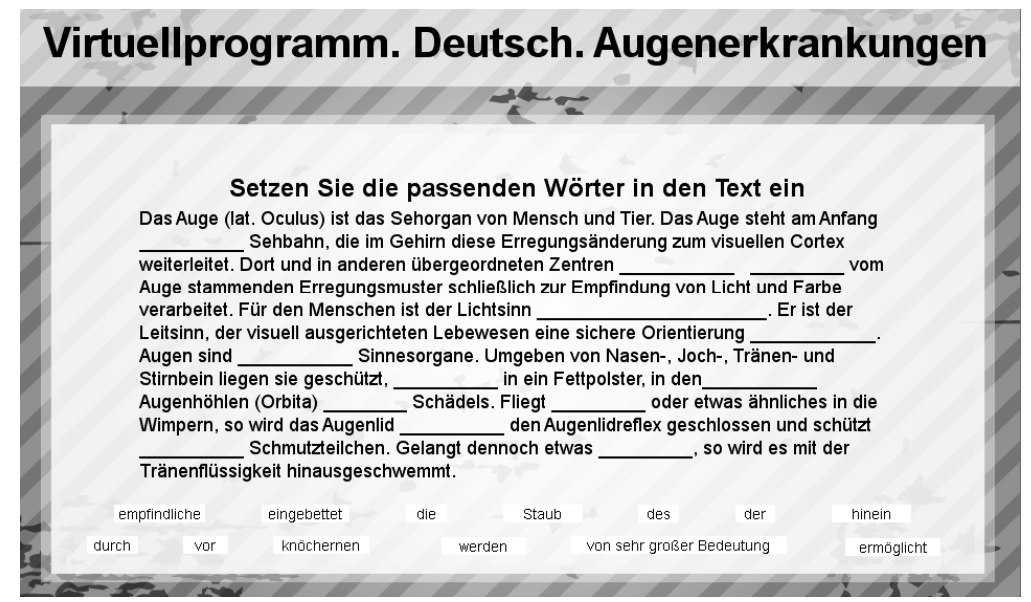

Рис. 7. Завдання на закріплення знань граматики німецької мови.

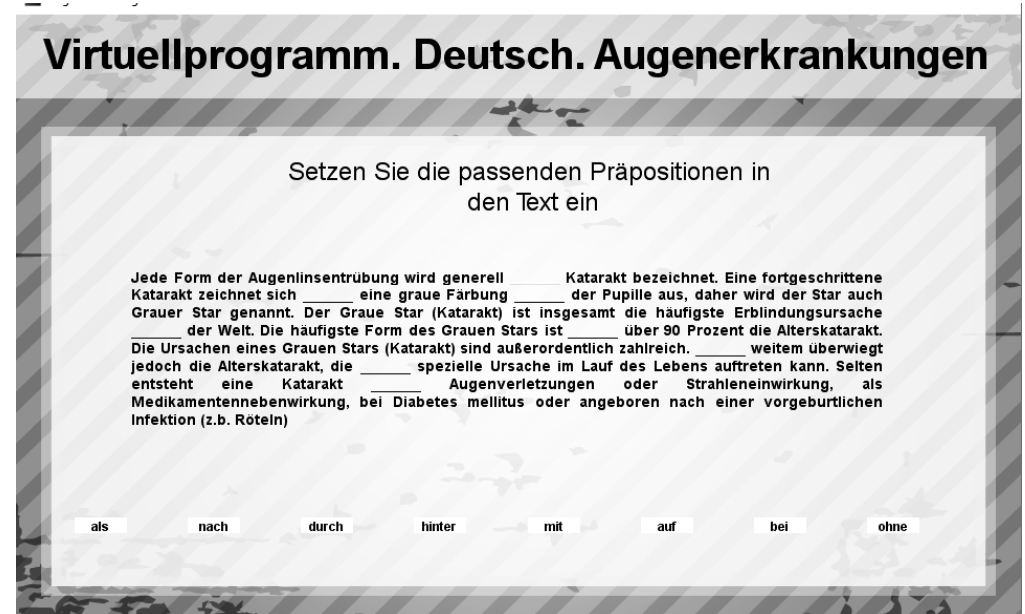

Рис. 8. Завдання на закріплення знань граматики німецької мови.

ми виявило такі результати. В опитування взяли участь 75 студентів II курсу медичного факультету ТДМУ. Студенти шляхом анкетування дали свою оцінку і результати показують таке: використання комп’ютера поліпшує навички граматики (93 \% респондентів); за допомогою віртуальної навчальної програми вони можуть цікаво вивчати матеріал, розв’язуючи конкретні ситуації (96 \% респондентів); такі заняття підвищують інтерес до предмета, сприяють запам'ятовуванню, розвивають уміння спілкуватися на основі виконання завдань та дозволяють перевірити й оцінити свої знання (98 \% респондентів); комп’ютер, зокрема віртуальна програма, сприяє поліпшенню їх словникового запасу та граматичної компетентності, оскільки $€$ тренінгові завдання різноманітного характеру (98 \% респондентів); заняття із використанням віртуальної навчальної програми стали цікавішими; вони краще розуміють матеріал і запам'ятовують його; їм хочеться самостійно працювати (98 \% респондентів); їхні викладачі заохочують студентів використовувати комп’ютерні технології для вивчення німецької мови (98 \% респондентів); заняття з використанням віртуальної навчальної програми сприяють засвоєнню та запам’ятовуванню навчального граматичного матеріалу (99 \% респондентів); заняття із використанням віртуальної навчальної програми подобається набагато більше, аніж традиційне заняття (100\% респондентів); 100 \% студентів цікаво, чи до кожної граматичної теми на заняттях будуть виконувати завдання із використанням віртуального середовища.

Висновки та перспективи подальших досліджень. Використання технологій у вивченні іноземної мови стало реальною необхідністю в наші дні. Як говорить китайське прислів’я: почую - забуду, побачу - запам'ятаю, зроблю сам - зрозумію. Саме тому ми пропонуємо таке. 3 метою покращення мовних навичок пропонуємо розглянути використання віртуальної навчальної програми як складової частини занять з німецької мови за професійним спрямуванням. Для ефективного навчання та викладання німецької мови за професійним спрямуванням варто у віртуальну навчальну про- 
граму включати завдання для вдосконалення мовних навичок (аудіювання, читання, письмо, говоріння). Результати роботи показують, що інформаційно-комунікаційні технології, зокрема віртуальна навчальна програма, мають величезний потенціал у підвищенні мотивації навчання у процесі вивчення іноземної мови за професійним спрямуванням, дають можливість роботи з автентичними, текстовими, аудіо- та відеоматеріалами, створюють умови для реалізації іншомовного потенціалу студентів. Віртуальна навчальна програма, поєднуючи в собі можливості книги, універсальної іграшки, телевізора, разом із тим є для студентів рівноправним партнером, здатним реалізувати їх запити. 3 іншого боку, цей метод навчання є привабливим і для викладача: допомагає об’єктивно оцінити іншомовні знання студента, спонукає до пошуку нових, нетра-

\section{Список літератури}

1. Чередніченко Г. А. Мультимедійні технології у процесі викладання дисципліни «Іноземна мова» у вищих технічних навчальних закладах / Г. А. Чередніченко, Л. Ю. Шапран, Л. І. Куниця // Наукові записки. Серія «Педагогіка» / Тернопільський національний педагогічний університет ім. В. Гнатюка. - 2011. - № 4. С. 134-138.

2. Яценко Ю. С. Интеграция информационно-коммуникационных технологий в процесс обучения иностранным языкам / Ю. С. Яценко // Преподаватель высшей школы в XXI веке : материалы Междунар. науч.практ. Интернет-конф., 30 марта 2007 г. - http://www.t21. rgups.ru/doc/5/21.doc.

\section{References}

1. Cherednichenko, H.A., Shapran, L.Yu., \& Kunytsia, L.I. (2011). Multymediini tekhnolohii u protsesi vykladannia dystsypliny "Inozemna mova” u vyshchykh tekhnichnykh navchalnykh zakladakh [Multimedia technologies in teaching foreign language in higher technical educational institutions]. Naukovi zapysky. Seriia: Pedahohika. Ternopilskyi natsionalnyi pedahohichnyi universytet im. V. Hnatiuka-Scientific Notes. Series" Pedagogy. V. Hnatiuk Ternopil National Pedagogical University, 4, 134-138 [in Ukrainian].

2. Yatsenko, Yu.S. (2007). Integratsiya informatsionnokommunikatsionnykh tekhnologiy v protsess obucheniya inostrannym yazykam [Integration of information and communication technologies in studying foreign languages]. Prepodavatel vysshey shkoly v XXI veke. Mezhdunarodnaya диційних методів і форми навчання, які будуть не лише цікавими, але й ефективними. Віртуальна навчальна програма дозволяє обирати послідовність вивчення матеріалу, сприяє індивідуалізації процесу навчання, урізноманітненню форм подання інформації, розширенню меж самостійної роботи студентів-медиків. Віртуальна навчальна програма дозволяє «занурення» студента в уявний світ, у певні ситуації та забезпечує можливість відтворення фрагмента навчальної діяльності. 3 метою модернізації навчального процесу з вивчення іноземної мови за професійним спрямуванням створити банк віртуальних навчальних програм.

Перспективи подальших досліджень вбачаємо у вивченні питання формування лексичної компетентності в контексті віртуального середовища.

3. Árkossy K. Didaktik-Methodik des Deutschunterrichts / Katalin Arkossy. - 2005. - Access mode : chrome-extension: // oemmndcbldboiebfnladdacbdfmadadm/http://gepeskonyv. btk.elte.hu/adatok/Germanisztika/113Szab\%F3/04\%20 Kapitel.pdf.

4. Fritzsche J. Zur Didaktik und Methodik des Deutschunterrichts / Joachim Fritzsche. - Verlag : Klett, 1999. - 265 S.

5. Tschekan K. Methoden im Unterricht SchleswigHolstein. Anregungen für Schule und Lehrerbildung / K. Tschekan. - Verl. Der echte Norden. www.iqsh.de. 2011. -42 S.

nauchno-prakticheskaya Internet-konferentsiya - High School Teacher in the XXI Century. International Scientific and Practical Internet Conference. March, 30. Retrieved from: http://www.t21.rgups.ru/doc/5/21.doc [in Russian].

3. Árkossy, K. (2005). Didaktik-Methodik des Deutschunterrichts. Retrieved from: chrome-extension: // oemmndcbldboiebfnladdacbdfmadadm/http://gepeskonyv. btk.elte.hu/adatok/Germanisztika/113Szab\%F3/04\%20 Kapitel.pdf.

4. Fritzsche, J. (1999). Zur Didaktik und Methodik des Deutschunterrichts. Verlag: Klett.

5. Tschekan, K. (2011). Methoden im Unterricht SchleswigHolstein. Anregungen für Schule und Lehrerbildung. Verl. Der echte Norden. Retrieved from: www.iqsh.de. 